\title{
Bone Disease in Chronic Childhood Cholestasis II. Better Absorption of 25-OH Vitamin D than Vitamin D in Extrahepatic Biliary Atresia
}

\author{
JAMES E. HEUBI, BRUCE W. HOLLIS, AND REGINALD C. TSANG
}

Divisions of Gastroenterology and Nutrition [J.E.H.], Neonatology [R.C.T.] and the Clinical Research Center [J.E.H.], Children's Hospital Research Foundation, Cincinnati, Ohio 45229; and Department of Pediatrics [B.W.H.], Medical University of South Carolina, Charleston, South Carolina 29425

\begin{abstract}
Infants with extrahepatic biliary atresia (EHBA) commonly develop rickets in infancy, whereas long-term survivors with EHBA commonly develop osteopenia with increasing age. We evaluated baseline vitamin $\mathrm{D}\left(\mathrm{D}_{2}\right.$ and $\left.\mathrm{D}_{3}\right), 25-\mathrm{OH}$ vitamin $\mathrm{D}_{2}$ and $\mathrm{D}_{3}, 1,25(\mathrm{OH})_{2}$ vitamin $\mathrm{D}$, bone mineral content, and vitamin $\mathrm{D}_{2}$ and 25 $\mathrm{OH}$ vitamin $\mathrm{D}_{3}$ absorption in six infants and children (age 4-22 mo) with EHBA whose portoenterostomy failed to produce bile flow (group 1) and five infants and children (age 10/12 to 8-4/12 y) with EHBA whose portoenterostomy repair led to good postoperative bile flow (group 2). Baseline serum vitamin $D_{2}$ and $D_{3}$ were undetectable in all subjects in group 1 despite supplements of 2500-5000 IU/ day, whereas all group 2 subjects given supplements (doses 400-5000 IU/d) had measurable levels. Baseline serum 25-OH vitamin $D$ was less than $15 \mathrm{ng} / \mathrm{mL}$ in five of six (three with rickets) in group 1 , whereas only one in group 2 had concentrations less than $15 \mathrm{ng} / \mathrm{mL}$. A significantly blunted rise of vitamin $D_{2}$ above baseline and reduced area under the absorption curve after $1000 \mathrm{IU} / \mathrm{kg}$ vitamin $D_{2}$ were found in group 1 patients compared to group 2 (both $p<0.01$ ), and five pediatric controls (both $p<0.01$ ). The peak change and area under the absorption curve for serum $25-\mathrm{OH}$ vitamin $\mathrm{D}_{3}$ from baseline after $10 \mu \mathrm{g} / \mathrm{kg} 25-\mathrm{OH}$ vitamin $D_{3}$ were significantly reduced for group 1 (both at least $p<0.05$ ) and group 2 compared to controls (both $p$ $<0.05$ ). Malabsorption of supplemental doses of vitamin $D$ compromises their efficacy to prevent rickets in infants with EHBA with poor bile flow after portoenterostomy. Despite severe malabsorption of vitamin $D$, we suggest that oral 25-OH vitamin D may be absorbed sufficiently to prevent rickets. (Pediatr Res 27:26-31, 1990)
\end{abstract}

\section{Abbreviations}

EHBA, extrahepatic biliary atresia PTH, parathyroid hormone

EHBA accounts for approximately $25 \%$ of cases of neonatal cholestasis (1). Operable forms with atresia limited to the distal portions of the biliary tract account for $10-15 \%$ of the cases. In

Received March 28, 1989; accepted Septmeber 7, 1989.

Correspondence and reprint requests James E. Heubi, M.D., Clinical Research Center, Children's Hospital Medical Center, Elland and Bethesda Avenues, Cincinnati, $\mathrm{OH} 45229$.

Supported in part by United States Public Health Service Grants Nos. HD 22542, HD 00479, HD 11725, and RR 00123 from the National Institutes of Health. recent years, surgical intervention for cases with no proximal duct remnant have prompted the construction of a Roux-en-Y of small intestine to the dissected liver hilum and resulted in postoperative bile flow, improvement in jaundice and survival for years in $40 \%$ of patients. Unfortunately, the remaining larger portion of subjects do not have "successful" operations and continue to have jaundice and poor bile flow postoperatively.

Infants with EHBA with poor biliary drainage after portoenterostomy have significant malabsorption of fat and fat-soluble vitamins because of intraluminal bile acid deficiency $(4,5)$. Apparently as a consequence, rickets occur in $59 \%$ of affected infants with unoperated EHBA (6). Results of previous studies in older children and adolescents with intrahepatic cholestasis have indicated that vitamin $\mathrm{D}$ is severely malabsorbed, whereas the absorption of $25-\mathrm{OH}$ vitamin $\mathrm{D}$ is less impaired (7). Our study was designed to evaluate vitamin $\mathrm{D}$ and $25-\mathrm{OH}$ vitamin $\mathrm{D}$ absorption in infants and children with EHBA and to test the hypothesis that, as found in older patients, $25-\mathrm{OH}$ vitamin $\mathrm{D}$ might be better absorbed than vitamin D in patients with EHBA, and therefore its use as a supplement would be superior to vitamin $\mathrm{D}$ for prevention of rickets.

\section{MATERIALS AND METHODS}

Patients and Controls. Group $1(n=6)$. Infants and children with EHBA (age 4/12 to 1-10/12 y) whose surgical exploration and formation of a portoenterostomy resulted in minimal postoperative bile flow (less than $10 \mathrm{~mL} / \mathrm{d}$ ), no reduction in serum bilirubin and an unfavorable clinical course characterized by poor growth, development of ascites, variceal bleeding in the first $2 \mathrm{y}$ of life. Orthotopic liver transplantation was performed in three subjects. Death occurred in two subjects after these studies were completed.

Group $2(n=5)$. Infants and children with EHBA (age 1 to $8-$ $4 / 12$ y) with good postoperative bile flow, reduction in serum bilirubin and a favorable clinical course characterized by only moderately impaired growth and no other significant hepaticrelated complications during the first 2 y of life.

Group $3(n=6)$. Control subjects (age 10/12 to $19-1 / 2$ y) with noncholestatic liver disease $(n=4)$ and idiopathic short stature $(n=2)$.

Baseline Evaluation. All patients were admitted to the General Clinical Research Center and fasting blood samples were obtained for baseline liver function tests (bilirubin, cholesterol, AST, ALT, alkaline phosphatase, total protein, albumin, prothrombin time, calcium, phosphorus, magnesium, PTH, and serum vitamin $\mathrm{D}$ metabolites (vitamin $\mathrm{D}_{2}$, vitamin $\mathrm{D}_{3}, 25-\mathrm{OH}$ vitamin $\mathrm{D}_{2}, 25-\mathrm{OH}$ vitamin $\mathrm{D}_{3}, 1,25(\mathrm{OH})_{2}$ vitamin $\left.\mathrm{D}\right)$. Plain radiographs of the wrists and/or knees and bone mineral concentration measurements were obtained. 
25-OH Vitamin $D_{3}$ Absorption. After a 4-h fast, a dose of 10 $\mu \mathrm{g} / \mathrm{kg}$ calcifediol (Calderol, Organon, W. Orange, $\mathrm{NJ}$ ) was given by mouth. Subjects and controls were allowed to eat an ageappropriate breakfast $2 \mathrm{~h}$ after dosing. Serial blood samples were obtained for measurement of $25-\mathrm{OH}$ vitamin $\mathrm{D}$ at time $0,+2$, $+4,+8$, and $+24 \mathrm{~h}$ as described by Stamp (8).

Vitamin $D_{2}$ Absorption. On a separate day, after a 4-h fast, a dose of $1000 \mathrm{IU} / \mathrm{kg}$ vitamin $\mathrm{D}_{2}$ (Drisdol, Winthrop Breon, New York, NY) was given by mouth. After $2 \mathrm{~h}$, the subjects were allowed to eat an age-appropriate breakfast. Blood was obtained for vitamin $\mathrm{D}_{2}$ and $\mathrm{D}_{3}$ at time $0,+4,+8,+12,+24$, and +48 hours, as outlined by Lo et al. (9).

This project was approved by the Institutional Review Board involving Human Subjects of the Cincinnati Children's Hospital Medical Center and the Scientific Advisory Committee of the General Clinical Research Center. Written informed consent was obtained from parents or guardians.

Analytical Methods. Baseline liver function tests, $\mathrm{Ca}, \mathrm{P}, \mathrm{Mg}$, and prothrombin times were measured by standard techniques in the clinical laboratories of the Children's Hospital Medical Center. PTH was measured using a RIA technique which measures amino acid 44-68 (Immunonuclear Corp., Stillwater, MN) with inter- and intraassay coefficients of variation of 14.0 and $6.6 \%$, respectively. Serum $25-\mathrm{OH}$ vitamin $\mathrm{D}$ analyzed for the $25-$ $\mathrm{OH}$ vitamin $\mathrm{D}$ tolerance tests was measured by a modification of Haddad and Chyu (10) using salicylic acid chromatography and rat serum binder with intraassay coefficients of variation for standards of $6.8 \%$ and for serum controls of $15 \%$.

Determination of serum vitamin $\mathrm{D}_{2}, \mathrm{D}_{3}, 25-\mathrm{OH}$ vitamin $\mathrm{D}_{2}$, $25-\mathrm{OH}$ vitamin $\mathrm{D}_{3}$, and $1,25(\mathrm{OH})_{2}$ vitamin $\mathrm{D}$ was accomplished using previously published techniques using solid-phase extraction of vitamin $\mathrm{D}$ and its metabolites from serum $(11-13)$. Vitamins $\mathrm{D}_{2}, \mathrm{D}_{3}, 25-\mathrm{OH}$ vitamin $\mathrm{D}_{2}$, and $25-\mathrm{OH}$ vitamin $\mathrm{D}_{3}$ were then quantitated by direct UV absorption after separation by high-performance liquid chromatography (13). 1,25(OH $)_{2}$ vitamin $\mathrm{D}$ levels were quantitated by a radioreceptor assay using the calf thymus receptor for $1,25(\mathrm{OH})_{2}$ vitamin $\mathrm{D}(11,12)$. Normal levels for pregnant white females receiving 400 IU vitamin $\mathrm{D}_{2} /$ day for vitamin $\mathrm{D}_{2}$ are $0-0.75 \mathrm{ng} / \mathrm{mL}$ and for vitamin $\mathrm{D}_{3}$ are $0-1.70 \mathrm{ng} / \mathrm{mL}$ (14). Normal values of total $25-$ $\mathrm{OH}$ vitamin $\mathrm{D}$ for adults using this technique are 15 to $50 \mathrm{ng} /$ $\mathrm{mL}$, whereas normal $1,25(\mathrm{OH})_{2}$ vitamin $\mathrm{D}$ concentrations are 30 to $50 \mathrm{pg} / \mathrm{mL}$. Inter- and intraassay coefficients of variation are $<10 \%$ for all of these determinations.
Bone mineral content was measured using direct single beam photon absorptiometry of the distal one-third site of the radius using a Lunar Bone Mineral analyzer that is specifically designed for use in infants and children. A narrow band of low-energy radiation $\left({ }^{125} \mathrm{I}\right)$ and a collimated scintillation detector were moved across the forearm. Bone mineral analysis by this method has been shown to indicate accurately ( 1 to $3 \%$ error) the ash weight of bone (15). Our interassay coefficient of variation is less than $6.5 \%$. All measurements were made on the left arm and the average of these measurements was used. Age- and sex-specific norms were used for comparisons because comparisons to single age-matched controls may not accurately reflect population normals $(16,17)$.

Statistical Analysis. All results are reported as the mean \pm SE. Statistical analyses included two-tailed Student's $t$ test and linear regression. Partial areas under the curve were calculated using the linear/logarithmic trapezoidal rule and were computed using PKCALC (18).

\section{RESULTS}

Clinical characteristics of both groups with extrahepatic biliary atresia are summarized in Table 1 . All subjects in group 1 had serum total bilirubin concentrations greater than $8.8 \mathrm{mg} / \mathrm{dL}$. Only one subject in group 2 (no. 1) had a markedly elevated total serum bilirubin $(7.3 \mathrm{mg} / \mathrm{dL})$. This patient remained jaundiced at age 43 mo but had no additional significant liver diseaserelated complications and was growing moderately well. Only one subject in group 1 (no. 3 ) had prolongation of prothrombin time of more than $3 \mathrm{~s}$ above control indicating hepatic synthetic function was maintained in most subjects. All but one subject were receiving supplemental vitamin D (400-5000 IU). One subject (group 2, no. 5) was receiving no vitamin $D$ supplement (see Table 2).

Serum calcium and phosphorus were both reduced in two subjects in group 1, whereas one subject had reduced serum calcium. All subjects with decreased serum calcium also have hypoalbuminemia. Serum magnesium was normal in all subjects. All subjects and controls had normal PTH concentrations. No subjects in group 1 had measurable vitamin D concentrations despite 2500-5000 IU/day supplement. In contrast, all subjects in group 2 who were receiving vitamin $D$ supplements had measurable serum vitamin D concentrations. In the one subject

Table 1. Patient characteristics

\begin{tabular}{|c|c|c|c|c|c|c|c|c|}
\hline & $\begin{array}{l}\text { Age } \\
(\mathrm{y})\end{array}$ & $\begin{array}{c}\mathrm{Wt} / \mathrm{Ht} \\
(\%)\end{array}$ & Sex & $\begin{array}{c}\text { Bilirubin } \\
\text { total / } \\
\text { direct } \\
(\mathrm{mg} / \mathrm{dL}) \\
\end{array}$ & $\begin{array}{l}\text { SGPT } \\
\text { (IU/L) }\end{array}$ & $\begin{array}{c}\text { Alkaline } \\
\text { phosphatase } \\
(\mathrm{U} / \mathrm{L})^{*}\end{array}$ & $\begin{array}{l}\text { Prothrombin } \\
\text { time/control } \\
\text { (s) }\end{array}$ & $\begin{array}{l}\text { Total } \\
\text { protein } / \\
\text { albumin } \\
(\mathrm{g} / \mathrm{dL})\end{array}$ \\
\hline \multicolumn{9}{|c|}{ Group 1: EHBA failed } \\
\hline 1 & $11 / 12$ & $<5 /<5$ & $\mathrm{~F}$ & $9.8 / 5.2$ & 94 & 1548 & $12.5 / 11.5$ & $5.9 / 2.1$ \\
\hline 2 & $6 / 12$ & $10 / 10$ & $F$ & $12.1 / 8.2$ & 159 & 1303 & $13.3 / 12.9$ & $5.7 / 3.5$ \\
\hline 3 & $6 / 12$ & $25 / 60 \dagger$ & $\mathrm{F}$ & $24.1 / 13.9$ & 146 & 1644 & $17.1 / 12.9$ & $5.0 / 2.4$ \\
\hline 4 & $4 / 12$ & $5 / 25$ & $\mathrm{~F}$ & $14.0 / 9.5$ & 158 & 1051 & $13.8 / 12.9$ & $6.0 / 3.5$ \\
\hline 5 & $10 / 12$ & $15 / 50$ & $\mathrm{~F}$ & $13.6 / 8.9$ & 239 & 1135 & $12.9 / 12.9$ & $4.9 / 2.7$ \\
\hline 6 & $1-10 / 12$ & $10 /<5 \dagger$ & M & $8.8 / 5.8$ & 195 & 1510 & $13.2 / 13.2$ & $5.1 / 3.0$ \\
\hline Range & $4 / 12-1 \quad 10 / 12$ & & & & & & & \\
\hline \multicolumn{9}{|c|}{ Group 2: EHBA Successful } \\
\hline 1 & $1-0 / 12$ & $25 / 25$ & $\mathrm{~F}$ & $7.3 / 5.7$ & 30 & 3168 & $10.3 / 11.5$ & $6.1 / 3.2$ \\
\hline 2 & $6-7 / 12$ & $5 / 5$ & M & $1.8 / 1.0$ & 144 & 2148 & $14.2 / 12.9$ & $6.5 / 3.6$ \\
\hline 3 & $8-4 / 12$ & $25 / 5$ & M & $1.7 / 1.0$ & 72 & 891 & $12.4 / 12.9$ & $5.2 / 2.2$ \\
\hline 4 & $7-9 / 12$ & $10 /<5$ & $\mathrm{~F}$ & $2.6 / 2.0$ & 83 & 2178 & $15.6 / 12.9$ & $5.9 / 2.8$ \\
\hline 5 & $4-0 / 12$ & $80 / 60$ & $\mathrm{~F}$ & $0.5 / 0.2$ & 143 & 1212 & $12.1 / 12.9$ & $6.6 / 4.3$ \\
\hline Range & $10 / 12-84 / 12$ & & & & & & & \\
\hline
\end{tabular}

* Laboratory reference: $140-325$ U/L, 0-2 y; 237-739 U/L, 2-17 y.

$\dagger$ Ascites present. 
Table 2. Baseline measurements of vitamin $D$ and mineral status

\begin{tabular}{|c|c|c|c|c|c|c|c|c|c|c|}
\hline & \multirow[b]{2}{*}{$\begin{array}{c}\mathrm{Ca} \\
(\mathrm{mg} / \mathrm{dL})\end{array}$} & \multirow[b]{2}{*}{$\begin{array}{c}\mathrm{P} \\
(\mathrm{mg} / \mathrm{dL})\end{array}$} & \multirow[b]{2}{*}{$\begin{array}{c}\mathrm{Mg} \\
(\mathrm{mg} / \mathrm{dL})\end{array}$} & \multirow[b]{2}{*}{$\begin{array}{c}\text { PTH } \\
(\mathrm{ng} / \mathrm{mL})\end{array}$} & \multicolumn{2}{|c|}{ Vitamin D } & \multicolumn{3}{|c|}{$25-\mathrm{OH}$ vitamin $\mathrm{D}$} & \multirow{2}{*}{$\begin{array}{c}1,25(\mathrm{OH})_{2} \\
\text { vitamin D } \\
(\mathrm{pg} / \mathrm{mL})\end{array}$} \\
\hline & & & & & $\begin{array}{c}\mathrm{D}_{2} \\
(\mathrm{ng} / \mathrm{mL})\end{array}$ & $\begin{array}{c}\mathrm{D}_{3} \\
(\mathrm{ng} / \mathrm{mL}) \\
\end{array}$ & $\begin{array}{c}\mathrm{D}_{2} \\
(\mathrm{ng} / \mathrm{mL})\end{array}$ & $\begin{array}{c}\mathrm{D}_{3} \\
(\mathrm{ng} / \mathrm{mL})\end{array}$ & Total & \\
\hline \multicolumn{11}{|c|}{ Group 1: EHBA failed } \\
\hline 1 & 8.2 & 2.5 & 1.8 & 0.3 & $<1$ & $<1^{*}$ & 8.2 & 5.6 & 13.8 & $30.7 \dagger$ \\
\hline 2 & 10.5 & 5.0 & 1.8 & 0.56 & $<0.5$ & $<0.5 \ddagger$ & 19.0 & 4.0 & 23.0 & 48.0 \\
\hline 3 & 8.5 & 4.3 & 1.9 & 0.54 & $<1$ & $<1^{*}$ & 8.9 & 2.1 & 11.0 & $41.6 \dagger$ \\
\hline 4 & 10.0 & 5.7 & 2.0 & $<0.3$ & $<1$ & $<1^{*}$ & 8.1 & 5.0 & 13.1 & 59.8 \\
\hline 5 & 9.3 & 5.6 & 2.1 & 0.53 & $<0.5$ & $<0.5^{*}$ & 12.6 & $<2$ & 12.6 & 38.2 \\
\hline 6 & 8.3 & 1.6 & 2.2 & 0.76 & $\mathrm{ND} \S$ & ND & $\mathrm{ND}$ & ND & $<5$ & $\mathrm{ND} \dagger$ \\
\hline \multicolumn{11}{|c|}{ Group 2: EHBA successful } \\
\hline 1 & 9.6 & 5.3 & 2.0 & 0.51 & 2.0 & $<1^{*}$ & 10.7 & 2.7 & 13.4 & 56.7 \\
\hline 2 & 9.2 & 4.8 & 1.6 & 0.4 & $<1$ & $6.8 \ddagger$ & 3.0 & 28.0 & 31.0 & 24.6 \\
\hline 3 & 8.7 & 3.2 & 1.7 & $<0.3$ & 6.9 & $1.0 \|$ & $<2$ & 21.5 & 21.5 & 23.2 \\
\hline 4 & 9.6 & 4.4 & 1.8 & 0.8 & 10.2 & $1.7^{*}$ & 31.9 & 4.8 & 36.7 & 18.4 \\
\hline 5 & 9.7 & 4.3 & 2.0 & 0.45 & $<.5$ & $<.5$ ब & $<2$ & 22.8 & 22.8 & 51.9 \\
\hline Normal & $\begin{array}{l}8.7-9.8 \\
(1-3 y) \\
8.8-10.1 \\
(4-9 y) \\
\end{array}$ & $\begin{array}{l}3.8-6.5 \\
(1-3 y) \\
4.1-5.4 \\
(4-6 y)\end{array}$ & $\begin{array}{l}1.6-2.6 \\
(1 \mathrm{mo}-2 \mathrm{y}) \\
1.5-2.4 \\
(2-6 \mathrm{y})\end{array}$ & $0.3-1.08$ & $0-.75$ & $0-1.70$ & & & $15-50$ & $30-50$ \\
\hline
\end{tabular}

* Supplemental vitamin $\mathrm{D}_{2}$ (per os) 2500-5000 IU/d.

$\dagger$ Patients with rickets.

\$ Supplemental vitamin $\mathrm{D}_{3}$ (per os) $2500 \mathrm{IU} / \mathrm{d}$.

$\S$ Not done.

II Supplemental vitamin $\mathrm{D}_{2}$ (per os) $400 \mathrm{IU} / \mathrm{d}$.

I No vitamin D supplement.

Table 3. Bone mineral content

\begin{tabular}{|c|c|c|c|}
\hline & $\begin{array}{l}\text { Bone mineral content } \\
\qquad(\mathrm{g} / \mathrm{cm})\end{array}$ & $\begin{array}{l}\text { Age-matched BMC } \\
(\text { mean } \pm \mathrm{SD})\end{array}$ & $\begin{array}{l}\text { Reduction versus control } \\
\text { (mean) }\end{array}$ \\
\hline \multicolumn{4}{|c|}{ Group 1: EHBA_-failed repair } \\
\hline 1 & 0.049 & $0.139 \pm 0.030$ & $3 \mathrm{SD}^{*}$ \\
\hline 2 & 0.076 & $0.1125 \pm 0.042$ & $1 \mathrm{SD}$ \\
\hline 3 & 0.087 & $0.139 \pm 0.030$ & $1-2 \mathrm{SD}^{*}$ \\
\hline 4 & 0.054 & $0.1125 \pm 0.042$ & 1-2 SD \\
\hline 5 & 0.082 & $0.1256 \pm 0.029$ & $1-2 \mathrm{SD}$ \\
\hline 6 & 0.141 & $0.161 \pm 0.031$ & $0-1 \mathrm{SD}^{*}$ \\
\hline \multicolumn{4}{|c|}{ Group 2: EHBA-successful repair } \\
\hline 1 & 0.101 & $0.139 \pm 0.030$ & $1-2 \mathrm{SD}$ \\
\hline 2 & 0.229 & $0.434 \pm 0.029$ & 2-3 SD \\
\hline 3 & 0.332 & $0.565 \pm 0.071$ & 3-4 SD \\
\hline 4 & 0.226 & $0.452 \pm 0.063$ & 3-4 SD \\
\hline 5 & 0.180 & $0.258 \pm 0.044$ & $1-2 \mathrm{SD}$ \\
\hline
\end{tabular}

* Patients with rickets.

receiving no supplement, serum vitamin $\mathrm{D}$ concentrations were not measurable.

In group 1, total serum $25-\mathrm{OH}$ vitamin $\mathrm{D}$ was less than $15 \mathrm{ng} /$ $\mathrm{mL}$ in five of six subjects. In each case, the $25-\mathrm{OH}$ vitamin $\mathrm{D}_{2}$ concentration (including the subject receiving supplemental vitamin $\mathrm{D}_{3}$ ) exceeded the $25-\mathrm{OH}$ vitamin $\mathrm{D}_{3}$ concentration. In group 2 , one subject had a total serum $25-\mathrm{OH}$ vitamin $\mathrm{D}$ concentration less than $15 \mathrm{ng} / \mathrm{mL}$. In this group, the distribution of $25-\mathrm{OH}$ vitamin $\mathrm{D}_{2}$ and $25-\mathrm{OH}$ vitamin $\mathrm{D}_{3}$ correlated well with serum vitamin $D_{2}$ and $D_{3}$ concentrations and whether patients received vitamin $\mathrm{D}_{2}$ or $\mathrm{D}_{3}$ supplementation.

Serum $1,25(\mathrm{OH})_{2}$ vitamin $\mathrm{D}$ concentrations were normal in all but one subject in group 1, whereas in group 2 three subjects had reduced concentrations and two were elevated. In the three subjects in group 1 with rickets, concentrations of $25-\mathrm{OH}$ vitamin $\mathrm{D}$ were reduced and $1,25(\mathrm{OH})_{2}$ vitamin $\mathrm{D}$ concentrations were normal.
Bone mineral content and radiograph findings are summarized in Table 3. Only one subject in group 1 had a significantly reduced bone mineral content compared to age-matched controls; this subject also had rickets. Two additional subjects with rickets had normal age-adjusted bone mineral content. Despite normal age-matched bone mineral content, all but one subject was between 1 and 2 SD less than the mean, indicating that bone accretion is reduced in these subjects. In contrast, three of five subjects in group 2 had reduced bone mineral content and concurrently had reduced $1,25(\mathrm{OH})_{2}$ vitamin D concentrations. Two additional subjects had bone mineral content 1-2 SD less than the mean, suggesting impaired bone accretion. None had rickets; however, all had subjective radiographic evidence of osteopenia.

Absorption Studies. Vitamin D. Administration of a weightadjusted dose of vitamin $D_{2}$ resulted in a peak change of serum vitamin $\mathrm{D}_{2}$ from baseline of $61.0 \pm 9.8 \mathrm{ng} / \mathrm{mL}$ (range $40.0-97.8$ 
$\mathrm{ng} / \mathrm{mL}$ ) in controls at 8 to $12 \mathrm{~h}$. In one control, the peak was reached at $4 \mathrm{~h}$. The area under the curve for the vitamin $D_{2}$ tolerance test was $1900 \pm 183 \mathrm{ng} \times \mathrm{h} / \mathrm{mL}$. Subjects in group 1 had either no rise in vitamin $D_{2}$ above baseline or, in two subjects, rises to a peak of 1.5 and $2.2 \mathrm{ng} / \mathrm{mL}$ (Fig. 1). The average peak rise above baseline was $0.9 \pm 0.6 \mathrm{ng} / \mathrm{mL}$ and the area under the curve for vitamin $\mathrm{D}_{2}$ absorption was $12.6 \pm 8.7$ $\mathrm{ng} \times \mathrm{h} / \mathrm{mL}$. In group 2 , the peak vitamin $\mathrm{D}_{2}$ concentration was $74.0 \pm 19.7 \mathrm{ng} / \mathrm{mL}$ (range $37-148 \mathrm{ng} / \mathrm{mL}$ ). Similar to the controls, the peak concentration was attained at $8 \mathrm{~h}$ in two subjects, $12 \mathrm{~h}$ in two subjects, and $4 \mathrm{~h}$ in one subject. The area under the curve for the vitamin $\mathrm{D}_{2}$ tolerance test was $1704 \pm 437 \mathrm{ng} \times \mathrm{h} /$ $\mathrm{mL}$ for group 2 subjects. No significant differences between control and group 2 subjects for changes in vitamin $\mathrm{D}_{2}$ concentrations were noted at any time point. In addition, no significant difference in peak concentration or area under the absorption curve was noted between controls and subjects in group 2 . In contrast, significant differences were noted in the peak change from baseline in serum vitamin $\mathrm{D}_{2}$ concentrations between both controls and group 2 subjects compared to subjects in group 1 at each time point (all $<0.001$ ). The peak concentration above baseline in group 1 subjects was significantly less than subjects in group $2(p<0.01)$ and controls $(p<0.001)$. Finally, the area under the absorption curve for vitamin $D_{2}$ in group 1 subjects was significantly reduced compared to group $2(p<0.01)$ and controls $(p<0.001)$.

$25-O H$ vitamin $D$. After a weight-adjusted dose of $25-\mathrm{OH}$ vitamin $\mathrm{D}_{3}$ was given to controls, a rise above baseline of 53 to $240 \mathrm{ng} / \mathrm{mL}$ above baseline (mean $117.2 \pm 19.8 \mathrm{ng} / \mathrm{mL}$ ) was found. The peak was seen between 3 and $8 \mathrm{~h}$ after administration of the test dose (Fig. 2) and the concentrations declined toward baseline at $24 \mathrm{~h}$. In subjects in group 1, the peak rise of $25-\mathrm{OH}$ vitamin $\mathrm{D}$ above baseline was $28.3 \pm 7.1 \mathrm{ng} / \mathrm{mL}$ with an area under the absorption curve of $335 \pm 99 \mathrm{ng} \times \mathrm{h} / \mathrm{mL}$. For subjects in group 2, the peak rise of 25-OH vitamin D above baseline was $46.0 \pm 15.8 \mathrm{ng} / \mathrm{mL}$ and the area under the absorption curve was $516.8 \pm 240.7 \mathrm{ng} \times \mathrm{h} / \mathrm{mL}$. Neither the peak nor the area under the curve values differed between groups 1 and 2 . In contrast, in the controls the peak $(117.2 \pm 19.8 \mathrm{ng} / \mathrm{mL})$ was significantly higher than group $1(p<0.001)$ and group $2(p<0.05)$. In addition, in the controls the area under the absorption curve for $25-\mathrm{OH}$ vitamin $\mathrm{D}(2020.7 \pm 471.5 \mathrm{ng} \times \mathrm{h} / \mathrm{mL})$ was significantly higher than group $1(p<0.001)$ and group $2(p<0.05)$.

\section{DISCUSSION}

EHBA is the cause of approximately $25 \%$ of conjugated hyperbilirubinemia presenting in infancy. The incidence of the

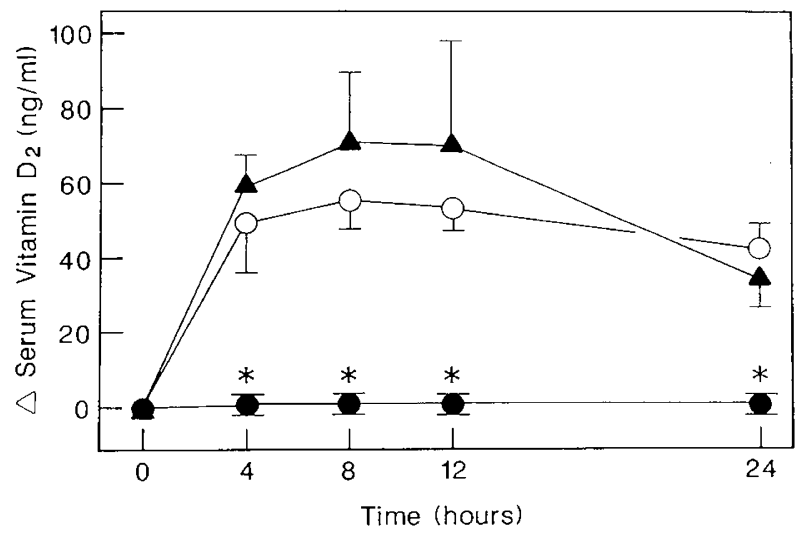

Fig. 1. Change in serum vitamin $D_{2}$ after a test dose of $1000 \mathrm{IU} / \mathrm{kg}$ vitamin $\mathrm{D}_{2}$ administered to infants and children with extrahepatic biliary atresia with poor results after portoenterostomy $(\boldsymbol{\bullet})$, infants and children with EHBA with good results after portoenterostomy $(\mathbf{\Lambda})$, and controls $(\mathrm{O}) .{ }^{*} p<0.02$ versus $\mathrm{EHBA}$ with good results and controls. All values represent mean $\pm \mathrm{SEM}$.

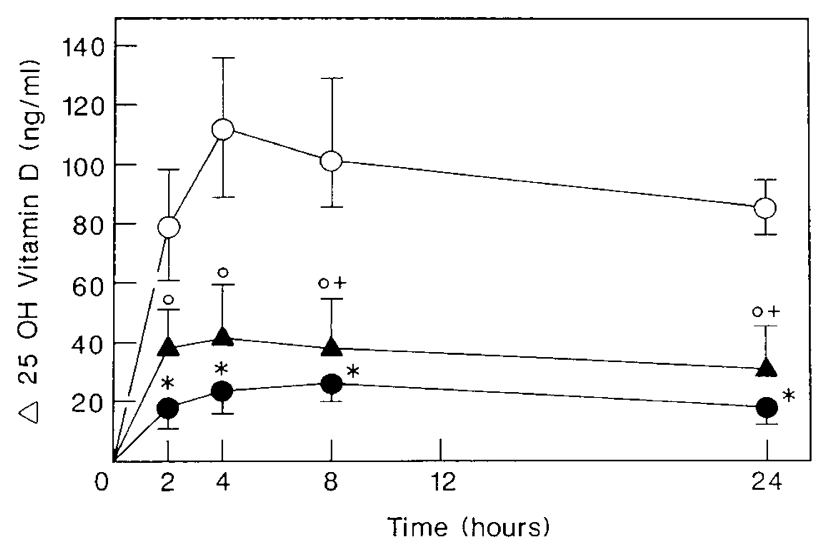

Fig. 2. Change in serum 25-OH vitamin D after a test dose of $10 \mu \mathrm{g} /$ $\mathrm{kg} 25-\mathrm{OH}$ vitamin D administered to infants and children with EHBA with poor results after portoenterostomy $(\bullet)$, infants and children with EHBA with good results after portoenterostomy $(\mathbf{\Lambda})$, and controls $(O)$. ${ }^{\circ} p=\mathrm{NS}$ versus $\mathrm{EHBA}$ with poor results, ${ }^{*} p<0.01$ versus controls, ${ }^{+} p<$ 0.05 versus controls.

disease is one in 10000 to 15000 live births (19). At operation, about $10-15 \%$ of infants will have patent proximal hepatic ducts that do not communicate with the duodenum. The remainder have obliteration of the extrahepatic ducts to varying extent but generally involving the entire extrahepatic biliary tree. In infants with "correctable" forms of biliary atresia, a Roux-en-Y anastomosis of jejunum to hepatic duct may be performed with favorable results. In infants with "noncorrectable" forms, portal dissection is undertaken with placement of a Roux-en-Y anastomosis of jejunum to the undersurface of the liver capsule (2). The magnitude of postoperative bile flow and resolution of jaundice are dependent on age at operation and ductal remnant size $(20,21)$. Most patients have failure of establishment of postoperative bile flow and pursue a course of progressive liver failure eventuating in death, or transplantation in the first $2 \mathrm{y}$ of life. A minority of patients has satisfactory postoperative bile flow, resolution of jaundice, and slow progression of portal cirrhosis with the development of portal hypertension with ascites and varices during the first decade of life.

Among patients with extrahepatic biliary atresia with poor immediate postoperative results, significant complications impair their quality of life. Rickets is a common complication and is found in $59 \%$ of surgically unrepaired infants with EHBA in a series by Kobayashi et al. (6) and 12/18 infants with cholestatic liver disease by Roberts et al. (22). The findings of reduced concentrations of serum $25-\mathrm{OH}$ vitamin $\mathrm{D}$ and response to massive parenteral doses of vitamin $D$ have led investigators to believe that severe intestinal malabsorption of vitamin $D$ is responsible for production of rickets and bone disease in infants and children with hepatobiliary disease (23-27).

In our study, we examined bone mineral content, baseline vitamin $\mathrm{D}$ metabolites, and absorption of vitamin $\mathrm{D}_{2}$ and 25$\mathrm{OH}$ vitamin $\mathrm{D}_{3}$ in infants and children with EHBA assigned to groups based on the success of the portoenterostomy. By definition, the groups differ substantially in age because patients with poor results rarely survive beyond age 2 y without orthotopic liver transplantation. However, there is no a priori reason to suggest that the age differences of the diseased patient groups or the controls should affect the results of the absorption studies. It is likely that the pathogenesis of bone disease in these patient groups may be multifactorial. In group 1, vitamin D deficiency plays a central role; however, additional factors also present in group 2 may affect bone mineral content. In the other group, factors such as reduced bone deposition, increased resorption or abnormal bone matrix may play more significant roles in the genesis of bone disease.

Radiographic evidence of rickets was present in three infants 
in group 1 with poor postoperative results. Only one had severely reduced bone mineral content $(-3 \mathrm{SD})$. In the other four subjects, bone mineral content was reduced relative to control values $(-1$ to $-2 \mathrm{SD})$. In contrast, three of five patients with "successful" repairs had significantly reduced bone mineral content and subjective evidence of osteopenia but no rickets. The apparent discrepancy between the finding of rickets without severe reduction in bone mineral content may relate to differences of bone site being examined. Rickets is usually diagnosed radiographically by changes observed at the distal end of the long bones such as the radius, whereas bone mineral content is measured as an average over the distal one-third site of the radius. Therefore, different mineralization processes are measured. Reduced bone mineral content in children more than 2 y of age (group 2) could reflect less rapid bone growth that is a reflection of prolonged abnormalities of bone metabolism. The specific etiology of the reduced bone density in older subjects theoretically might relate to reduced $1,25(\mathrm{OH})_{2}$ vitamin $\mathrm{D}$ concentrations, alterations in osteocalcin metabolism, exercise, chronic mineral malabsorption, or other nutritional factors. Preliminary results in subjects similar to those presented here suggest that calcium absorption is not impaired (28). The most plausible hypothesis that may explain all of the biochemical derangements associated with reduced bone density is reduced exercise and activity in chronically ill children with liver disease. Strain imposed on bone by activity most likely diverts calcium and phosphorus from blood to bone. As a consequence, PTH secretion increases leading to increased $1,25(\mathrm{OH})_{2}$ vitamin D secretion (29-32). Although the effects of exercise have been studied in adults, no such studies have been performed in normal or diseased infants. This is also the subject of current investigation at our research unit.

Measurable serum vitamin $\mathrm{D}_{2}$ or $\mathrm{D}_{3}$ was found in all subjects with successful portoenterostomies who were receiving vitamin D supplements and the distribution of $25-\mathrm{OH}$ vitamin $\mathrm{D}$ metabolites reflected the supplemented component. No subjects with a poor result after portoenterostomy had measurable serum vitamin $\mathrm{D}_{2}$ or $\mathrm{D}_{3}$ concentrations. In all but one subject with a poor result after portoenterostomy (group 1), serum $25-\mathrm{OH}$ vitamin $\mathrm{D}$ concentrations were below the lower limits of normal. Three of these five subjects also had rickets. Surprisingly, measurable $25-\mathrm{OH}$ vitamin $\mathrm{D}_{2}$ concentrations were present despite the demonstration, in our study, that no measurable vitamin $\mathrm{D}_{2}$ appeared in the serum after a test dose of $1000 \mathrm{IU} / \mathrm{kg}$. Measurable serum $25-\mathrm{OH}$ vitamin $\mathrm{D}_{2}$ may result from release of $25-\mathrm{OH}$ vitamin $\mathrm{D}_{2}$ stores (such as during fetal life) or minimal absorption of large doses of vitamin $\mathrm{D}_{2}$ administered on a daily basis to the subjects. Both possibilities are currently being examined. In previous studies in older cholestatic subjects, measurable $25-\mathrm{OH}$ vitamin $D_{2}$ was also found with large oral vitamin $D_{2}$ supplements and no measurable serum vitamin $\mathrm{D}_{2}(7)$.

Serum $1,25(\mathrm{OH})_{2}$ vitamin $\mathrm{D}$ concentrations were variable in both groups. In the patients with "failed" portoenterostomies, the concentrations were normal or minimally increased, a finding previously observed (28). In contrast, in the older subjects with "successful" portoenterostomies, concentrations were either normal or low. Those with low concentrations had consistently reduced $1,25(\mathrm{OH})_{2}$ vitamin $\mathrm{D}$ concentrations. This finding is consistent with our previous work in older children with intrahepatic cholestasis and studies in adults $(7,34-36)$. The reasons for the observed alterations in $1,25(\mathrm{OH})_{2}$ vitamin $\mathrm{D}$ concentrations are unknown. In the younger subjects, it would be anticipated that $1,25(\mathrm{OH})_{2}$ vitamin $\mathrm{D}$ concentrations would rise in the face of rickets or calcium deficiency as a compensatory mechanism to increase the efficiency of intestinal absorption and maximize calcium economy. In the older subjects, reduced concentrations cannot be explained. It is hypothesized that they may relate to 1 ) increased turnover and 2) impaired synthesis that may relate to chronic liver disease and decreased activity.

Vitamin $\mathrm{D}_{2}$ absorption was absent or minimal after an oral test dose in patients with "failed" portoenterostomies. This ob- servation is consistent with findings in older patients with intrahepatic cholestasis (7). In contrast, in patients with "successful" portoenterostomies, and presumably adequate intraluminal bile salt concentrations, the rise of vitamin $\mathrm{D}_{2}$ above baseline after an oral test dose was similar to controls. Therefore, it appears that vitamin $D_{2}$ absorption is unaffected when bile flow is reestablished in patients with extrahepatic biliary atresia. In addition, the observation of measurable or even high concentrations of serum vitamin $\mathrm{D}$ in these patients chronically supplemented with doses ranging from only 400 to $5000 \mathrm{IU} /$ day reinforces the notion that vitamin $\mathrm{D}$ absorption is intact.

Absorption of 25-OH vitamin D appeared to be less impaired than vitamin D in patients with "failed" portoenterostomies. This finding is similar to observations in older children and adults $(7,37)$. Animal studies have suggested that $1,25(\mathrm{OH})_{2}$ vitamin $D$ and $25-\mathrm{OH}$ vitamin $\mathrm{D}$ are better absorbed than vitamin $\mathrm{D}$ in the absence of bile salts $(38,39)$. With increasing hydroxylation of the sterol ring of vitamin $\mathrm{D}$, the molecule becomes more polar, more water soluble, and therefore better absorbed. Despite impaired uptake of $25-\mathrm{OH}$ vitamin D, it would be anticipated that chronic administration would reliably allow maintenance of normal serum concentrations. In both children and adults with chronic cholestatic disease, chronic administration of $25-\mathrm{OH}$ vitamin D has raised serum concentrations (27, 35). Daum et al. (27) have previously treated three patients with extrahepatic biliary atresia with daily $50 \mu \mathrm{g} 25-\mathrm{OH}$ vitamin $\mathrm{D}$ with improvement in serum concentrations and improvement in rickets. Impaired 25-OH vitamin D absorption despite normal vitamin $\mathrm{D}$ absorption in patients with good bile flow was unexpected and a specific reason is not readily apparent. Studies are currently underway in our laboratories to investigate optimal dosages and the effect of chronic therapy with $25-\mathrm{OH}$ vitamin $\mathrm{D}$ on bone density and serum concentrations in infants with chronic cholestasis.

Sunlight exposure might be a reliable means to stimulate endogenous synthesis of vitamin $\mathrm{D}$ in these patient populations. Unfortunately, patients with portoenterostomy repair that does not reestablish bile flow tend to be debilitated and, in many cases, hospital bound. For this group, the use of $25-\mathrm{OH}$ vitamin $\mathrm{D}$ appears to be a logical choice to prevent rickets and optimize bone metabolism before orthotopic liver transplantation. Unfortunately, because the pathogenesis of bone disease in all patients may relate, in part, to alterations in activity, it may be extremely difficult to normalize bone metabolism.

Acknowledgments. The authors thank the parents and study children for their help and cooperation, the Children's Hospital Clinical Research Center and its nurses for their invaluable assistance, Andrea Smith for essential secretarial assistance and R. C. Schumaker for use of the PKCALC computer program.

\section{REFERENCES}

1. Balistreri WF 1981 Neonatal cholestasis. In: Lebenthal E (ed) Textbook of Gastroenterology and Nutrition in Infancy. Raven Press, New York, pp 1081-1107

2. Ryckman FC, Noseworthy $\mathbf{J} 1987$ Neonatal cholestatic conditions requiring surgical reconstruction. Semin Liver Dis 7:134-154

3. Altman RP, Stolar CJH 1985 Pediatric hepatobiliary disease. Surg Clin North Am 65:1245-1267

4. Sokol RJ 1987 Medical management of the infant or child with chronic liver disease. Semin Liver Dis 7:155-167

5. Kaufman SS, Murray ND, Wood RP, Shaw BW Jr, Vanderhoof JA 1987 Nutritional support for the infant with extrahepatic biliary atresia. J Pediatr 110:679-686

6. Kobayashi A, Kawai S, Utsunomiya T, Ohbe Y 1974 Bone disease in infants and children with hepatobiliary disease. Arch Dis Child 49:641-646

7. Heubi JE, Hollis BW, Specker B, Tsang RC 1989 Bone disease in chronic childhood cholestasis. I. Vitamin D absorption and metabolism. Hepatology 9:258-264

8. Stamp TCB 1974 The intestinal absorption of 25-hydroxycholecalciferol. Lancet 2:121-123

9. Lo CW, Paris PW, Clemens TL, Nolan J, Holick MF 1985 Vitamin D 
absorption in healthy subjects and in patients with intestinal malabsorption syndromes. Am J Clin Nutr 42:644-649

10. Haddad JC, Chyu RJ 1971 Competitive protein binding radioassay for 25 hydroxy-cholecalciferol. J Clin Endocrinol 33:992-995

11. Reinhardt TA, Horst RL, Orf JW, Hollis BW 1984 A microassay for $1,25(\mathrm{OH})_{2} \mathrm{D}$ not requiring high performance liquid chromatography: application to clinical studies. J Clin Endocrinol Metab 58:91-98

12. Hollis BW 1986 Assay of circulating $1,25(\mathrm{OH})_{2} \mathrm{D}$ involving a novel singlecartridge extraction and purification procedure. Clin Chem 32:2060-2063

13. Hollis BW, Frank NE 1985 Solid phase extraction system for vitamin D and its major metabolites in human plasma. J Chromatogr 343:43-49

14. Hollis BW, Pittard WB 1984 Evaluation of the total fetomaternal vitamin D relationship at term: evidence for race differences. J Clin Endocrinol Metab 59:652-657

15. Mazess RB, Cameron JR, O'Connor R, Knutzen D 1964 Accuracy of bone mineral measurement. Science 145:388-389

16. Specker BL, Brazerol W, Tsang RC, Levin R, Searcy J, Steichen J 1987 Bone mineral content in children 1 to 6 years of age. Am J Dis Child 141:343344

17. Mazess RB, Cameron JR 1973 Bone mineral content in normal U.S. whites. In: Mazess RB (ed) International Conference on Bone Mineral Measurement. DHEW, Washington, DC, publ 75-683, pp 228-238

18. Schumaker RC 1986 PKCALC: a basis interactive computer program for statistical and pharmacokinetic analysis of data. Drug Metabol 17:331-348

19. Danks DM, Campbell PE, Jack I, Rogers J, Smith AL 1977 Studies of the aetiology of neonatal hepatitis and biliary atresia. Arch Dis Child 52:360367

20. Kasai M, Suzuki H, Ohaski E, Ohi R, Chiva T, Okamoto A 1978 Technique and results of operative management of biliary atresia. World J Surg 2:571580

21. Chandra RS, Altman PR 1978 Ductal remnants in extrahepatic biliary atresia: a histopathologic study with clinical correlation. J Pediatr 93:196-200

22. Roberts CC, Book LS, Chan GM, Matlak ME 1981 Rickets in children with cholestatic liver disease: evaluation and treatment. Pediatr Res 15:544(abstr)

23. Seino Y, Shimotsuji T, Kai H, Ikehara C, Yabuuchi H 1978 The plasma levels of 25-hydroxyvitamin $D$ in patients with various liver diseases and the response of 25-hydroxyvitamin D to vitamin D treatment. Acta Paediatr Scand 67:39-42

24. Kimura S, Seino Y, Harada T, Nose O, Yamaoka K, Shimizu K, Tanaka H, Yabuuchi H, Fukui Y, Kamata S, Okada A 1988 Vitamin D metabolism in biliary atresia: Intestinal absorptions of 25-hydroxyvitamin $D_{3}$ and 1,25dihydroxyvitamin $\mathrm{D}_{3}$. J Pediatr Gastroenterol Nutr 7:341-346
25. Kooh SW, Jones G, Reilly BJ, Fraser D 1979 Pathogenesis of rickets in chronic hepatobiliary disease in children. J Pediatr 94:870-874

26. Heubi JE, Tsang RC, Steichen JJ, Chan GM, Chen I-W, DeLuca HF 1979 1,25-dihydroxyvitamin $\mathrm{D}_{3}$ in childhood hepatic osteodystrophy. $\mathrm{J}$ Pediat 94:977-982

27. Daum F, Rosen JF, Roginsky M, Cohen MI, Finberg L 1976 25-hydroxycholecalciferol in the management of rickets associated with extrahepatic biliary atresia. J Pediatr 88:1041-1043

28. Bucuvalas JC, Heubi JE, Yergey A, Specker B 1988 Intestinal calcium absorption in children with cholestatic liver disease. Pediatr Res 23:299(abstr)

29. Bell NH, Epstein S, Greene A, Shary J, Oexmann MJ, Shaw S 1985 Evidence for alteration of the vitamin $\mathrm{D}$-endocrine system in obese subjects. $\mathrm{J}$ Clin Invest 76:370-373

30. Bell NH, Greene A, Epstein S, Oexmann MJ, Shaw S, Shary J 1985 Evidence for alteration of the vitamin D-endocrine system in blacks. J Clin Invest $76: 470-473$

31. Pocock NA, Eisman JA, Yeates MG, Sambrook PN, Eberl S 1986 Physical fitness is a major determinant of femoral neck and lumbar spine bone mineral density. J Clin Invest 78:618-621

32. Dalsky GP, Stocke KS, Ehsani AA, Slatopolsky E, Lee WC, Birge SJ, Jr 1988 Weight-bearing exercise training and lumbar bone mineral content in postmenopausal women. Ann Intern Med 108:824-828

33. Farrell MK, Heubi JE, Tsang RC, Dodson D, Ho M 1981 Normal or elevated 1,25-dihydroxy vitamin $\mathrm{D}_{3}\left(1,25(\mathrm{OH})_{2} \mathrm{D}\right)$ in childhood cholestasis. Pediatr Res 15:1118 (abstr)

34. Bengoa JM, Sitrin MD, Meredith S, Kelly SE, Shah N, Baker AL, Rosenberg IH 1984 Intestinal calcium absorption and vitamin D status in chronic cholestatic liver disease. Hepatology 4:261-265

35. Kaplan MM, Goldberg MJ, Matloff DS, Neer RM, Goodman DBP 1984 Effect of 25-hydroxyvitamin $D_{3}$ on vitamin $D$ metabolites in primary biliary cirrhosis. Gastroenterology 81:681-685

36. Bikle DD, Gee E, Halloran B, Haddad JG 1984 Free 1,25-dihydroxyvitamin $D$ levels in serum from normal subjects, pregnant subjects and subjects with liver disease. J Clin Invest 74:1966-1971

37. Sitrin MD, Bengoa JM 1987 Intestinal absorption of cholecalciferol and 25 hydroxycalciferol in chronic cholestatic liver disease. Am $\mathrm{J}$ Clin Nutr 46:1011-1015

38. Nechama H, Hoff D, Harell A, Edelstein S 1977 The intestinal absorption of vitamin D and its metabolites. J Molec Med 2:413-422

39. Sitrin MD, Pollack KL, Bolt MJG, Rosenberg IH 1982 Comparison of vitamin $D$ and 25-hydroxyvitamin D absorption in the rat. Am J Physiol 242:G326G332 